\title{
UJI EFEK ANALGETIK EKSTRAK ETANOL RIMPANG JAHE PUTIH (Zingiber officinale Rosc.var. Amarum) PADA TIKUS PUTIH JANTAN GALUR WISTAR (Rattus norvegicus)
}

\author{
Beatriks Lahamendu ${ }^{1)}$, Widdhi Bodhi ${ }^{1)}$, Jainer Pasca Siampa ${ }^{1)}$ \\ ${ }^{1)}$ Program Studi Farmasi FMIPA UNSRAT Manado, 95115
}

\begin{abstract}
White Ginger Rhizome (Zingiber officinale Rosc.var. Amarum) contains secondary metabolites such as flavonoids, there are also several compounds such as gingerol, shogaol, and zhigeron which provide anti-inflamatory, antioxidant, analgesic, anticarsinogenic and cardiotonic effects. This study aims to determine the analgesic effect of ethanol extracts of white ginger rhizome with different doses, namely the treatment group 1, dose $0.006 \mathrm{~g}$, the Treatment Group 2, dose $0.012 \mathrm{~g}$ and the Treatment Group 3, dose $0.024 \mathrm{~g}$ tested on white male wistar strain rats. This study uses a laboratory experimental research design using male white rats as experimental animals. The result of the study using LSD showed a difference between the group of negative control and the group of positive control, and also the treatment group with extracts with significance value $(0.014,0.008$, 0.012 and 0.005 ) the value $<0.05$, which indicates that according to the hypothesis namely rejecting $\mathrm{HO}$ and accepting $\mathrm{HI}$, which means significantly different between the negative control group with positive control group and the treatment group with extracts, but there is no difference between the positive control group and the treatment group with extract which means there is no difference because they both have analgesic effects. From the results of the study it can be concluded that the ethanol extracts of white ginger rhizome at a dose $0.006 \mathrm{~g}, 0.012 \mathrm{~g}$, and $0.024 \mathrm{~g}$ has analgesic effects in male white wistar strain rats can be seen from the decreasing number of rat responses (licks and jumps).
\end{abstract}

Keywords: Analgesic, anova, White Ginger Rhizome, White male wistar strain

\begin{abstract}
ABSTRAK
Rimpang Jahe putih (Zingiber officinale Rosc.var amarum) mengandung metabolit sekunder seperti flavonoid juga terdapat beberapa senyawa seperti gingerol, shogaol, dan zingeron yang memberikan efek antiinflamasi, antioksidan, analgetik, antikarsinogenik dan kardiotonik. Penelitian ini bertujuan untuk mengetahui adanya efek analgetik dari ekstrak etanol rimpang jahe putih dengan dosis yang berbeda-beda yaitu Kelompok Perlakuan 1 dosis 0,006 g, kelompok Perlakuan 2 dosis 0,012 g dan Kelompok Perlakuan 3 dosis 0,024 g yang diuji pada tikus putih jantan galur wistar. Penelitian ini menggunakan rancangan penelitian eksperimental laboratorium dengan menggunakan tikus putih jantan sebagai hewan percobaan. Hasil penelitian menggunakan LSD menunjukkan adanya perbedaan antara kelompok kontrol negatif dengan kelompok kontrol positif, dan juga kelompok perlakuan dengan ekstrak dengan nilai signifikansi $(0,014,0,008,0,012$ dan 0,005$)$ nilai tersebut $<0,05$ yang menandakan bahwa sesuai hipotesis yaitu menolak H0 dan menerima H1 yang berarti berbeda secara signifikan antara kelompok kontrol negatif dengan kontrol positif dan kelompok perlakuan dengan ekstrak,tapi tidak terdapat perbedaan antara kelompok kontrol positif dengan kelompok perlakuan dengan ekstrak yang berarti tidak memiliki perbedaan karena sama-sama memiliki efek analgetik. Dari hasil penelitian dapat disimpulkan bahwa ekstrak etanol rimpang jahe putih dengan dosis $0,006 \mathrm{~g}, 0,012 \mathrm{~g}$ dan 0,024 $\mathrm{g}$ memiliki efek analgetik pada tikus putih jantan galur wistar dapat dilihat dari menurunnya jumlah respon tikus (jilatan dan lompatan).
\end{abstract}

Kata kunci : Analgetik, anova, rimpang Jahe putih, tikus Putih jantan galur wistar 


\section{PENDAHULUAN}

Nyeri adalah pengalaman sensorik dan emosional yang tidak menyenangkan akibat kerusakan jaringan, baik aktual maupun potensial atau yang digambarkan dalam bentuk kerusakan tersebut. Rasa nyeri dalam kebanyakan hal merupakan suatu gejala yang berfungsi untuk melindungi tubuh. Nyeri harus dianggap sebagai isyarat bahaya tentang adanya gangguan jaringan, seperti peradangan, infeksi jasad renik, atau kejang otot (Tjay, 2007).

Beberapa senyawa yang ada pada jahe putih seperti gingerol, shogaol, dan zingeron memberikan efek antiinflamasi, antioksidan, analgesik, antikarsinogenik, dan kardiotonik. Bahan aktif jahe dilaporkan dapat juga menstimulus pencernaan, mengurangi konstipasi dan gas dalam perut dengan meningkatkan aktivitas dari otot saluran pencernaan. Masih terdapat banyak efek lain yang diberikan oleh tanaman jahe, seperti efek pada kanker usus, efek pada tekanan darah serta juga sebagai efek analgetik (Ghosh $e t$ $a l, 2011)$.

Rimpang pada jahe mengandung flavonoid, 10-dehydrogingerione, gingerdione, arginin, linolenic acid, aspartia acid, kanji, lipid, kayu damar, asam amino, protein, vitamin $\mathrm{A}$ dan niacin serta mineral. Terdapat juga asam-asam organik seperti asam malat, asam oksalat, vitamin A, B (Collin dan folat) dan C, senyawa senyawa flavonoid, polifenol, aseton, methanol, cineole dan arginine (Setyawan, 2015).

\section{METODOLOGI PENELITIAN}

\section{Waktu dan Tempat Penelitian}

Penelitian ini dilakukan pada bulan Mei 2019 sampai bulan Agustus 2019 di Laboratorium Farmasi Lanjut, Program Studi Farmasi, Fakultas Matematika dan Ilmu Pengetahuan Alam, Universitas Sam Ratulangi.

\begin{abstract}
Alat
Alat yang digunakan dalam penelitian ini antara lain : alat-alat gelas $\left(\right.$ Pyrex $\left.^{\circledR}\right)$, blender $\left(\right.$ Philips $\left.^{\circledR}\right)$, ayakan, oven, wadah, sarung tangan, masker, timbangan analitik (ADAM,KERN), sudip, kertas saring, lumpang dan alu, waterbath, stopwatch, disposable syringe $1 \mathrm{ml}$, dan sonde Oral, aluminium foil, toples.
\end{abstract}

\section{Bahan}

Bahan yang digunakan dalam penelitian ini adalah: Rimpang Jahe putih, tablet Parasetamol $500 \mathrm{mg}$, makanan hewan uji, CMC 1\%, etanol $96 \%$ dan aquadest.

\section{Hewan Uji}

Objek yang digunakan dalam penelitian merupakan tikus putih jantan galur wistar (Rattus norvegicus) sebanyak 15 ekor dan dibagi dalam 5 kelompok perlakuan, dimana setiap kelompok terdiri dari 3 ekor tikus dengan berat 100-200 gram.

\section{Rancangan Penelitian}

Penelitian ini menggunakan
rancangan penelitian eksperimental
laboratorium dengan menggunakan tikus
putih jantan galur wistar (Rattus
norvegicus) sebagai hewan percobaan.


Perlakuan dibagi dalam 5 kelompok, dalam kelompok masing-masing terdiri dari 3 ekor tikus yang sudah diadaptasikan terlebih dahulu terhadap lingkungan selama 10 hari. Pembagian kelompok perlakuan sebagai berikut :

\begin{tabular}{|c|c|}
\hline$(-)$ & $\begin{array}{l}\text { : diberikan suspensi CMC } 1 \% \\
\text { sebanyak } 1 \mathrm{ml}\end{array}$ \\
\hline $\mathrm{K}(+)$ & $\begin{array}{l}: \text { diberikan Parasetamol dosis } \\
12,6 \mathrm{mg}\end{array}$ \\
\hline $\mathrm{P} 1$ & $\begin{array}{l}\text { : diberikan suspensi ekstrak } \\
\text { etanol rimpang jahe putih dosis } \\
0,006 \mathrm{~g}\end{array}$ \\
\hline $\mathrm{P} 2$ & $\begin{array}{l}\text { diberikan suspensi ekstrak } \\
\text { etanol rimpang jahe putih dosis } \\
0,012 \mathrm{~g}\end{array}$ \\
\hline P3 & $\begin{array}{l}\text { diberikan suspensi ekstrak } \\
\text { etanol rimpang jahe putih dosis } \\
0,024 \mathrm{~g}\end{array}$ \\
\hline
\end{tabular}

\section{Pembuatan Simplisia dan Proses Ekstraksi}

Sampel rimpang jahe putih yang telah diambil kemudian dicuci dengan air mengalir dengan tujuan menghilangkan pengotor dan ditimbang sebanyak $5 \mathrm{~kg}$. Kemudian dipotong kecil-kecil untuk mempermudah proses pengeringan. Pengeringan sampel dilakukan dengan cara diangin-anginkan selama 5 hari. Sampel yang sudah kering kemudian diblender hingga menjadi serbuk dan ditimbang. Serbuk yang dihasilkan diayak dengan ayakan, hingga diperoleh serbuk halus. Serbuk rimpang jahe putih ditimbang sebanyak 400 gram, dimasukkan ke dalam wadah, kemudian ditambahkan pelarut etanol 96\% sebanyak $2000 \mathrm{ml}$ dengan perbandingan 1:5, ditutup dan dibiarkan selama 5 hari terlindung dari cahaya (setiap hari sampel diaduk). Setelah 5 hari, rendaman tersebut disaring dengan menggunakan kertas saring sehingga menghasilkan filtrat dan debris. Selanjutnya dilakukan proses remaserasi dengan ekstrak etanol 96\% sebanyak 1200 $\mathrm{ml}$ selama 2 hari. Filtrat hasil maserasi dan hasil dari remaserasi digabung kemudian dimasukkan ke dalam oven pada suhu $40^{\circ}$ C dengan tujuan untuk pemekatan ekstrak sampai menjadi ekstrak kental.

\section{Pembuatan Larutan CMC 1\%}

Sebanyak 1 gram CMC ditaburkan dalam beaker glass yang berisi $10 \mathrm{ml}$ aquades yang telah dipanaskan, aduk sampai mengembang kemudian dihaluskan sampai homogen. Selanjutnya dimasukkan ke dalam labu ukur dan ditambahkan aquades sampai volume $100 \mathrm{ml}$.

\section{Dosis Parasetamol}

Tiap tablet Parasetamol mengandung $500 \mathrm{mg}$. Takaran konversi dosis parasetamol untuk manusia dengan berat badan $70 \mathrm{~kg}$ pada tikus dengan berat badan 200 g adalah 0,018. Rata-rata orang Indonesia beratnya $50 \mathrm{~kg}$, maka dosis untuk tikus adalah :

$=\left(\frac{70 \mathrm{~kg}}{50 \mathrm{~kg}} \times 500 \mathrm{mg}\right) \times 0,018$

$=12,6 \mathrm{mg} / 200 \mathrm{~g}$ BB tikus

\section{Dosis Ekstrak Rimpang Jahe Putih}

Takaran konversi dosis untuk manusia dengan BB $70 \mathrm{~kg}$ pada tikus dengan BB 200 gram adalah 0,018. Ratarata orang Indonesia beratnya $50 \mathrm{~kg}$. Dosis pemakaian rimpang jahe putih pada manusia dewasa $(50 \mathrm{~kg})$ yang biasa digunakan Masyarakat adalah 15 gram, maka Dosis untuk Tikus digunakan Rumus sebagai berikut : 
$=$ (berat manusia / berat rata-rata orang indonesia $\mathrm{x}$ dosis rimpang jahe putih yang digunakan masyarakat) $\mathrm{x}$ takaran konversi dosis dari manusia ke tikus.

Dalam percobaan digunakan dosis ekstrak etanol rimpang jahe putih yang bertingkat :

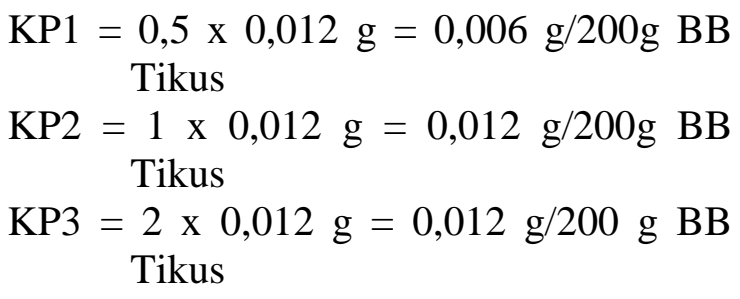

\section{Induksi Nyeri Cara Termik}

Uji efek analgetik menggunakan induksi nyeri dengan cara termik yaitu dengan cara memasukkan tikus ke dalam glass kimia yang telah dipanaskan diatas waterbath pada suhu $53^{\circ} \mathrm{C}$ sebagai stimulus nyeri dan tikus akan memberikan respon dalam bentuk menjilat kaki dan atau melompat.

\section{Pengujian Efektivitas Analgetik}

Langkah-langkah pengujian efek analgetik pada hewan uji ialah sebagai berikut :

a. Glass kimia diletakkan diatas waterbath yang dipanaskan hingga suhu $53^{\circ} \mathrm{C}$, tikus dimasukkan ke dalam glass kimia tersebut.

b. Setelah tikus ada di dalam glass kimia maka responnya diamati, yaitu berupa gerakan menjilat kaki belakang dan atau melompat. Pengamatan dilakukan selama 1 menit.

c. Kelompok Kontrol Negatif diberikan CMC 1\%, kelompok kontrol positif diberikan parasetamol dan kelompok perlakuan diberikan ekstrak etanol rimpang jahe putih. Tikus lalu diistirahatkan untuk diamati kembali pada menit ke-30.

d. Pengamatan dilakukan hingga menit ke 120, dengan interval waktu 30 menit untuk setiap pengamatan.

e. Pengamatan dilakukan sebanyak 5 kali, yaitu :

1. Sebelum pemberian bahan uji

2. Menit ke-30

3. Menit ke-60

4. Menit ke-90

5. Menit ke-120

\section{Analisis Data}

Data hasil pengamatan dikumpulkan dan disajikan dalam bentuk tabel, grafik dan analisis statistic menggunakan uji One-Way ANOVA (Analysis Of Variance). Untuk mengetahui pengaruh ekstrak etanol rimpang jahe putih terhadap tikus putih jantan galur wistar (Rattus norvegicus) dan menggunakan Least Significant Difference (LSD) untuk menguji signifikansi dari perbedaan ratarata antar kelompok perlakuan. 


\section{HASIL DAN PEMBAHASAN}

Data hasil penelitian berikut merupakan data yang diperoleh dari 5 kelompok perlakuan hewan uji yang masing-masing terdiri dari 3 ekor tikus.
Nilai rata-rata penurunan respon tikus (jilatan \& lompatan) terhadap kontrol negatif, kontrol positif dan ekstrak etanol rimpang jahe putih dapat dilihat pada tabel 1 berikut ini :

Tabel 1. Hasil dari perhitungan rata-rata penurunan respon tikus

\begin{tabular}{|c|c|c|c|c|c|}
\hline \multirow{2}{*}{$\begin{array}{l}\text { Kelompok } \\
\text { Perlakuan }\end{array}$} & \multirow{2}{*}{$\begin{array}{l}\text { Sebelum } \\
\text { Pemberian } \\
\text { Bahan Uji }\end{array}$} & \multicolumn{4}{|c|}{ Setelah Perlakuan } \\
\hline & & Menit ke 30 & Menit ke 60 & Menit ke 90 & Menit ke 120 \\
\hline Kontrol Negatif & 18,3 & 15,3 & 15 & 16 & 17,6 \\
\hline Kontrol Positif & 14,3 & 11,6 & 0,6 & 0,3 & 0 \\
\hline KP1 Dosis 0,006 g & 13,3 & 7 & 0,6 & 0 & 0 \\
\hline KP2 Dosis 0,012 g & 22,6 & 2 & 0 & 0 & 0 \\
\hline KP3 Dosis 0,024 g & 14,6 & 1 & 0 & 0 & 0 \\
\hline $\begin{array}{ll}\text { Ket : } & \\
\text { Kontrol Negatif : CN } \\
\text { Kontrol Positif } & : \text { P } \\
\text { KP1 } & : \text { E } \\
\text { KP2 } & : \text { E } \\
\text { KP3 } & : \text { E }\end{array}$ & $\begin{array}{l}\text { C } 1 \% \\
\text { casetamol Dos } \\
\text { strak Etanol r } \\
\text { strak Etanol r } \\
\text { strak Etanol ri }\end{array}$ & $\begin{array}{l}12,6 \mathrm{mg} / 20 \\
\text { apang Jahe Pu } \\
\text { apang Jahe Pu } \\
\text { ppang Jahe Pu }\end{array}$ & $\begin{array}{l}\text { g BB Tikus } \\
\text { h Dosis } 0,006 \\
\text { h Dosis } 0,012 \\
\text { h Dosis } 0,024\end{array}$ & & \\
\hline
\end{tabular}

Pada penelitian ini yang digunakan sebagai objek (hewan uji) penelitian adalah Tikus putih jantan yang telah diadaptasikan dengan lingkungan selama 10 hari. Penggunaan tikus putih sebagai hewan uji dikarenakan tikus putih telah dikenal sebagai model hewan percobaan yang baik, mudah ditangani, dapat diperoleh dalam jumlah besar, dan memberi hasil nilai ulangan yang dapat dipercaya (Gelfand, 2002). Pemilihan galur wistar dikarenakan tikus wistar mempunyai kemampuan metabolisme yang relatif cepat sehingga lebih sensitif bila digunakan dalam penelitian yang berhubungan dengan metabolism tubuh
(Aminah,2004). Menurut Pujiatiningsih (2014), penggunaan tikus putih jantan sebagai binatang percobaan dapat memberikan hasil penelitian yang lebih stabil karena tidak dipengaruhi oleh adanya siklus menstruasi dan kehamilan seperti pada tikus putih betina. Tikus putih jantan juga mempunyai kecepatan metabolisme obat yang lebih cepat dan kondisi biologis tubuh yang lebih stabil dibanding tikus betina.

Jumlah respon tikus terhadap rangsangan nyeri diamati sebelum akan diberikan bahan uji, tujuannya yaitu agar dapat dilihat perbedaan yang ada baik 
sebelum pemberian bahan uji ataupun sesudah pemberian bahan uji.

Rendemen adalah perbandingan antara ekstrak yang diperoleh dengan simplisia awal. Rendemen menggunakan satuan persen $(\%)$, semakin tinggi nilai rendemen yang dihasilkan menandakan nilai ekstrak yang dihasilkan semakin banyak. Hasil rendemen sampel untuk ekstrak etanol rimpang jahe putih adalah sebanyak $8 \%$ artinya setelah melalui proses pengeringan, rimpang jahe putih kehilangan berat sebesar 92\%. Untuk rendemen ekstrak yang diperoleh sebesar $1,60 \%$ nilai yang didapat oleh rendemen ekstrak bernilai kecil yang menandakan bahwa untuk menghasilkan rendemen ekstrak yang banyak memerlukan sampel rimpang jahe putih yang banyak pula.

Penelitian ini bertujuan untuk melihat apakah ekstrak etanol rimpang jahe putih memiliki efek analgetik atau tidak terhadap tikus putih jantan dengan menggunakan induksi nyeri cara termik yaitu dengan cara memasukkan tikus kedalam glass kimia yang telah dipanaskan terlebih dahulu diatas waterbath pada suhu $53^{\circ} \mathrm{C}$ dan pada hewan percobaan akan memberikan respon terhadap nyeri dalam bentuk menjilat kaki belakang atau loncat (Puspitasari, et al., 2003). Digunakan rentang suhu $45-55^{\circ} \mathrm{C}$ karena menurut (Guyton, 1994) pada suhu $45^{\circ} \mathrm{C}$ seseorang mulai merasakan sakit dan reseptor panas mempunyai respon terhadap suhu $30-45^{\circ} \mathrm{C}$ dan suhu diatas $45^{\circ} \mathrm{C}$ mulai terjadi kerusakan jaringan akibat panas dan sensasinya berubah menjadi nyeri. Nyeri ini disebabkan oleh stimulus panas yang merangsang reseptor nyeri yang sensitif terhadap suhu panas atau suhu dingin yang ekstrim yaitu termosensitif.

Dari hasil yang didapat Terlihat bahwa CMC yang digunakan sebagai kontrol negatif, tidak menunjukkan adanya efek analgetik yang terjadi, dapat dilihat dari kenaikan gerakan baik berupa jilatan atau lompatan dari tikus putih lebih meningkat bahkan sampai pada menit yang ke 120. Itu dapat disebabkan karena pada kontrol negatif tidak terkandung zat aktif yang dapat mengurangi nyeri.

Untuk Parasetamol dengan dosis 12,6 mg menunjukkan adanya efek analgetik yang terjadi karena seiring dengan berjalannya waktu respon yang diberikan oleh hewan uji lebih menurun jika dibandingkan dengan kelompok kontrol negatif yang memiliki kenaikan respon dari tikus. Ini menunjukkan bahwa Parasetamol memiliki efek analgetik pada tikus.

Untuk ekstrak etanol rimpang jahe putih dengan dosis 0,006 $\mathrm{g}$ dapat dilihat respon tikus yang terjadi yaitu mengalami penurunan itu menunjukkan bahwa ekstrak etanol rimpang jahe putih dengan dosis 0,006 g memiliki efek analgetik karena dilihat dari respon tikus yang mulai menurun bahkan pada saat menit yang ke 120 tikus tidak mempunyai pergerakan seperti menjilat kaki belakang ataupun melompat.

Pada dosis ekstrak jahe yang kedua yaitu dengan dosis 0,012 $\mathrm{g}$ dapat dilihat respon tikus yang terjadi antara rata-rata sebelum pemberian bahan uji dan menit ke 30 mempunyai respon yang cukup jauh respon penurunannya. Begitu juga yang terjadi dengan dosis ekstrak yang ketiga dengan dosis 0,024 g. ini dapat menunjukkan bahwa ekstrak etanol 
rimpang jahe putih memiliki efek analgetik bahkan dosis yang dipakai dalam penelitian ini memiliki dosis yang rendah yaitu $0,006 \mathrm{~g}, 0,012 \mathrm{~g}$ dan dosis $0,024 \mathrm{~g}$.

Ekstrak etanol rimpang jahe putih memiliki efek analgetik sesuai dengan penelitian yang dilakukan oleh (Raji dkk, 2002) dengan menggunakan tikus dewasa wistar strain albino dengan berat 180-190 g dan menggunakan mencit dengan berat 20$25 \mathrm{~g}$ untuk menguji efek analgetik dari rimpang jahe, metode yang digunakan yaitu mencit yang diinduksi asam asetat untuk menimbulkan rangsangan nyeri, hasilnya yaitu ekstrak rimpang jahe dengan dosisi (50 dan $100 \mathrm{mg} / \mathrm{kg}$ ) berat badan) secara signifikan mengurangi jumlah menggeliat pada mencit yang telah diinduksi dengan asam asetat. Jumlah geliat yang terlihat menurun menunjukkan adanya efek analgetik dari rimpang jahe.

Uji homogenitas digunakan untuk mengetahui apakah beberapa varian populasi adalah sama atau tidak. Untuk hasil uji Homogenitas varian yang dilakukan pada setiap kelompok perlakuan, hasil analisis menunjukkan nilai yaitu 0,107 dimana nilai tersebut $>0,05$ maka dapat disimpulkan bahwa varian data yang ada homogen. Karena menurut Priyatno (2009), Jika nilai signifikan lebih besar dari 0,05 maka dapat dikatakan bahwa varian dari dua atau lebih kelompok adalah sama.

Hasil analisis statistik uji anova menunjukkan nilai $0,028(<0,05)$ dimana hasil yang didapat ditunjukkan hipotesis yaitu menolak $\mathrm{H} 0$ dan meneriman $\mathrm{H} 1$, maka didapatkan hasil bahwa terdapat perbedaan yang bermakna antar kelompok perlakuan. Untuk Uji ANOVA hanya memberikan indikasi tentang ada tidaknya beda antar rata-rata dari keseluruhan perlakuan, namun belum memberikan informasi tentang ada tidaknya perbedaan antara kelompok perlakuan yang satu dengan kelompok perlakuan lainnya. Untuk itu perlu dilakukan uji LSD setelah dilakukannya uji one way anova agar dapat terlihat lebih spesifik kelompok perlakuan mana yang memiliki perbedan yang bermakna antar tiap kelompok perlakuan.

Pada uji LSD (Least Signifficant Difference) terdapat perbedaan antara kelompok kontrol negatif dengan kelompok kontrol positif, begitu juga dengan kelompok kontrol negatif dengan kelompok perlakuan 1, kelompok perlakuan 2 dan juga kelompok perlakuan 3. Namun tidak terdapat perbedaan antara kelompok kontrol positif dengan kelompok perlakuan menggunakan ekstrak jahe yang menandakan bahwa ekstrak jahe memiliki efek analgetik sama seperti kelompok kontrol positif. Dimana untuk hasil kontrol negatif dengan kelompok kontrol positif dan Kelompok Perlakuan 1, Kelompok Perlakuan 2, dan Kelompok Perlakuan 3 dengan nilai signifikansi $(0,014,0,008$, 0,012, dan 0,005) dari hasil ini dapat dilihat bahwa nilai tersebut $<0.05$ yang menandakan bahwa sesuai dengan hipotesis yang ada menolak $\mathrm{H} 0$ dan terima H1 yang berarti memiliki perbedaan antara kelompok kontrol negatif dengan kontrol positif dan Kelompok Perlakuan 1, Kelompok Perlakuan 2 dan Kelompok Perlakuan 3. Terdapat perbedaan karena kelompok kontrol negatif tidak memiliki efek analgetik sedangkan kelompok kontrol positif dan KP1, KP2 dan KP3 memiliki efek analgetik.

Untuk uji LSD antara kelompok kontrol positif dengan KP1, KP2, dan KP3 
tidak memiliki perbedaan. Itu dapat dilihat dari hasil nilai signifikansi yang ada yaitu ( untuk KP1 0,812, KP2 0,962 dan KP3 dengan nilai 0,635$)$ nilai yang didapat dari kelompok ekstrak jahe ini menunjukkan nilai > 0,05 yang berarti tolak $\mathrm{H} 1$ dan terima $\mathrm{H} 0$ yang berarti tidak ada perbedaan antara kelompok kontrol positif dan KP1, KP2 dan KP3. Itu menandakan bahwa kelompok ini sama-sama memiliki efek analgetik sehingga tidak terdapat perbedaan.

Dilihat dari hasil yang didapat dari ketiga dosis ekstrak etanol rimpang jahe putih yang diberikan, penelitian ini membuktikan bahwa secara farmakologis tanaman jahe putih memiliki efek analgetik.

Ekstrak rimpang jahe putih memiliki efek analgetik karena adanya kandungan flavonoid dan juga beberapa senyawa yang ada pada rimpang jahe putih seperti gingerol, shogaol, dan zingeron memberikan efek antiinflamasi, antioksidan,analgesik, kardiotonik antikarsinogenik.

\section{KESIMPULAN}

Dari hasil penelitian dapat disimpulkan bahwa ekstrak etanol rimpang jahe putih (Zingiber officinale Rosc.var. Amarum) dengan dosis 0,006 g, 0,012 g, dan dosis 0,024 g memiliki efek analgetik pada tikus putih jantan galur wistar (Rattus norvegicus) dapat dilihat dengan menurunnya jumlah respon tikus (jilatan dan lompatan) setelah diberikan ekstrak rimpang jahe putih.

\section{SARAN}

Perlu dilakukannya penelitian lebih lanjut mengenai penentuan dosis minimum, dosis maksimum, dan juga dosis toksik dari ekstrak rimpang jahe putih (Zingiber officinale Rosc.var. Amarum).

\section{DAFTAR PUSTAKA}

Aminah R. 2004. Pengembangan Model Kesehatan Koloni Tikus dan Mencit Percobaan Ditinjau dari Aspek Hematologis, Parasitologis, dan Histologis. Center for Research and Development of Disease Control.

Gelfand EW. 2002. Pro: Mice Are a Good Model of Human Airway Disease. Am J Respir Crit CareMed. 166(1):5-8.

Ghosh, A. K., Banerjee, S., Mullick, H.I., and Banerjee, J. 2011. Zingiber officinale : A natural gold. Inj. J. Pharma Bio Sci, 2(1), pp. 283-94.

Guyton, A.C. 1994. Buku Ajar Fisiologi Kedokteran. Terjemahan K.A. Tengadi. Jakarta : EGC.

Pujiatiningsih, Agatha Sri, 2014. Pemberian Ekstrak Daun Putri Malu (Mimosa pudica Linn) secara Oral Menurunkan Kadar Gula Darah Post Prandial pada xvii Tikus (Rattus Norvegicus) Jantan Galur Wistar Perdiabetesi. Diss. [Tesis] untuk Memperoleh Gelar Magister.

Puspitasari, Hesti., Listyawati, Shanti dan Widiyani, Tetri., 2003. Aktivitas Analgetik Ekstrak Umbi Teki (Cyperus rotundus L.) pada Mencit Putih (Mus musculus L.) Jantan. Biofarmasi, ISSN: 1693-2242, 1(2), 56.

Priyatno Dwi. 2009. Mandiri Belajar SPSS. Yogyakarta: Mediakom.

Raji, Y., Udoh US, Oluwadara OO, Akinsomisoye OS, Awobajo O, Adeshoga K,. 2002. AntiInflammatory And Analgesic Properties Of The Rhizome Extract Of Zingiber Officinale, J.Biomed.,Res, vol 5,121-124.

Setyawan B. 2015. Peluang Usaha Budidaya Jahe. Edisi ke-1. Editor: Mona. Yogyakarta: Pustaka Baru Press;17- 24. 